\title{
PROGRAM PEMBERDAYAAN EKONOMI MANDIRI MELALUI BUDIDAYA PERIKANAN DAN PERKEBUNAN DALAM EMBER DI PANTI ASUHAN BUDI MULYA 2
}

\author{
Rahmalia Syahputri ${ }^{1 *}$, Jaka Darmawan ${ }^{2}$, Nurfiana $^{3}$, Ari Widiantoko ${ }^{4}$ \\ ${ }_{1,3,4}$ Fakultas Ilmu Komputer, Institut Informatika dan Bisnis Darmajaya \\ ${ }_{2}^{2}$ Fakultas Ekonomi Bisnis, Institut Informatika dan Bisnis Darmajaya \\ Email: 1rahmalia@darmajaya.ac.id; 2jakadarmawan@darmajaya.ac.id; \\ 3nurfiana@darmajaya.ac.id; ${ }^{4}$ ariwidiantoko@darmajaya.ac.id \\ *Penulis korespondensi
}

\begin{abstract}
Abstrak: Panti asuhan Budi Mulya 2 (BM 2) adalah satu satu lembaga sosial yang berlokasi di Bandar Lampung. Dalam memenuhi kebutuhan operasional pembangunan, operasional seharihari panti dan anak asuh, serta pengembangannya, BM 2 mengandalkan donasi yang diberikan oleh Donatur tetap dan tidak tetap, sehingga biaya pengembangan panti dan anak asuh tidak stabil, sangat kecil, dan tidak mencukupi. Agar lembaga dapat memiliki dana yang cukup untuk pengembangan baik fisik dan non fisik, sehingga anak asuh dapat termaksimalkan proses pembinaannya, maka Perlu direncanakan dan dikembangkannya usaha yang terarah dan berkesinambungan. Sebagai salah satu upaya, untuk itu, telah dicanangkan program jangka panjang tiga tahun pemberdayaan ekonomi mandiri melalui budidaya perikanan dan perkebunan dalam ember. Melalui kegiatan ini diharapkan terbentuknya sebuah lembaga pengabdian dan pendidikan masyarakat yang dinamis dan mampu menampung dan membina banyak anakanak terlantar melalui program peningkatan usaha ekonomi mandiri. Tulisan ini memaparkan hasil pengabdian selama tahun pertama kegiatan pengabdian; antara lain telah diselenggarakannya pembangunan dan pelatihan budidaya, panen pertama, dan beberapa kegiatan pada masa pandemic COVID-19. Selain itu, bertambahnya keterampilan Pengasuh dan Anak asuh dalam membudidayakan ikan dan tanaman dalam ember.
\end{abstract}

Kata kunci: Pemberdayaan, Mandiri, Ekonomi, Panti Asuhan, Budikdamber

\begin{abstract}
Budi Mulya 2(BM2) orphanage is a social institution located in Bandar Lampung. To meet the operational needs of development, the day-to-day operations of the orphanage, as well as their development, BM 2 rely on donations provided by permanent and non-permanent donors, thus the cost of developing the homes and foster children is unpredictable, very small, and insufficient. For an institution to have sufficient funds for both physical and non-physical development to allow foster children can be maximized for their guidance process, it is necessary to plan and develop a focused and sustainable business. As one of the efforts is conducting a longterm three-year program to empower the economy independently through aquaculture and plantations in buckets. By doing this action, it is hoped we can build a community service and education institution that is dynamic and capable of accommodating and fostering many neglected children through an independent economic enterprise improvement program. This paper describes the results of the service during the first year of service activities; which are the construction and cultivation training, the first harvest, and several activities during the COVID19 pandemic had been held. In addition, the skills of the caregiver and foster children improve in cultivating fish and plants in buckets.
\end{abstract}

Keywords: Empowering, Independent, Economic, Orphanage, Budikdamber.

\section{PENDAHULUAN}

Mendapatkan tempat tinggal yang layak, kesempatan menempuh pendidikan, terpenuhi kebutuhan pangannya merupakan hak setiap anak yang dipenuhi oleh keluarganya. Namun, tidak semua anak memiliki kesempatan yang sama dalam perolehan haknya, seperti anak fakir dan terlantar. Untuk itu, seusai dengan Amanat UUD 1945 pasal 34 ayat, fakir miskin dan anak terlantar 
dijamin oleh Negara. Tanggung jawab sosial membuat masyarakat turut berpartisipasi untuk mengemban tanggung jawab tersebut salah satunya melalui pembangunan dan pengelolaan panti asuhan sebagai keluarga alternatif bagi anak fakir dan terlantar.

Menurut Departemen Sosial (Artikel: Lembaga Kesejahteraan Sosial Anak (LKSA), n.d.) panti asuhan adalah lembaga kesejahteraan sosial yang mempunyai tanggung jawab untuk memberikan pelayanan kesejahteraan sosial kepada anak terlantar dengan melaksanakan penyantuan dan pengentasan anak terlantar. Selain itu, memberikan layanan pengganti fisik, mental, dan sosial anak asuh. Sehingga nantinya mereka memperoleh kesempatan yang luas, tepat, dan memadai untuk perkembangan kepribadiannya. Kedepannya anak terlantar dapat menjadi bagian dari generasi penerus cita-cita bangsa dan turut aktif dalam pembangunan nasional.

Adapun jenis usaha kesejahteraan anak berdasarkan Peraturan Pemerintah No. 2 Tahun 1988 Pasal 6 ayat 2 menyatakan bahwa asuhan diberikan antara lain berupa (Peraturan Pemerintah, 1988):

1) Penyuluhan, bimbingan, dan bentuk bantuan lainnya yang diperlukan;

2) Penyantunan dan pengentasan anak;

3) Pemberian/peningkatan derajat kesehatan;

4) Pemberian/peningkatan kesempatan belajar;

5) Pemberian/peningkatan keterampilan.

Berdasarkan hal tersebut, panti asuhan idealnya tidak hanya sebagi tempat tinggal, seyogyanya memiliki program yang terarah dan berkesinambungan untuk memastikan anak asuh memiliki keterampilan teknis, sosial, dan personal untuk bekal mereka nantinya saat terjun di masyarakat.

Untuk menjalankan fungsinya, mayoritas panti asuhan mengandalkan pendapatan dari donatur tetap dan tidak tetap untuk membiayai pengeluaran dibidang operasional, pembangunan, dan pengembangan. Dalam jangka pendek, hal ini mungkin tidak menimbulkan permasalahan, tetapi untuk jangka panjang tentu saja membutuhkan biaya yang tidak sedikit dan berkesinambungan.

Selain pembiayaan yang bergantung dengan donatur, panti asuhan belum dikelola dengan professional dikarenakan keterampilan pengurus dalam manajerial, khususnya yang terkait dengan: manajemen dan program pembinaan, manajemen anak asuh, manajemen keuangan dan pembiayaan, dan manajemen sarana dan prasarana. Hal ini mengakibatkan panti asuhan lemah dalam perencanaan dan inovasi program pembinaan sehingga hanya mengandalkan pendidikan disekolah. Akibatnya, anak asuh kurang terampil, pembukuan yang tidak memadai dan belum mencerminkan kondisi keuangan lembaga, sarana dan prasarana yang belum terkelola dengan baik, dan lembaga tidak mandiri secara ekonomi. Hal ini dialami banyak panti asuhan, pada (Nurfiana, 2020) mengatakan 100\% responden (4 panti asuhan di Bandar Lampung) menyatakan bahwa fasilitas, pengawasan, dan kegiatan (perencanaan dan pelaksanaan) adalah kendala dalam mengelola panti, sedangkan $75 \%$ responden menganggap bahwa pendanaan termasuk kendala.

Panti Asuhan Budi Mulya 2 (BM2) adalah satu satu lembaga sosial di Bandar Lampung. Pembangunan fisik panti dimulai sejak 2008 dengan dana yang bersumber dari Pengurus, Pemerintah, swasta, dan perorangan. Panti ini mulai menerima anak asuh pada Juli 2018. Saat ini ada 12 anak asuh yang berasal dari berbagai daerah di Lampung antara lain Lampung Selatan, Tanggamus, dan Lampung Timur yang 3 orang diantaranya disekolahkan di SMA, sisanya sisanya SMP. Dalam memenuhi kebutuhan operasional pembangunan, operasional sehari-hari panti dan anak asuh, serta pengembangannya, BM 2 mengandalkan donasi yang diberikan oleh Donatur tetap dan tidak tetap dengan rata-rata pemasukan 12.000 .000 perbulan. Sedangkan pengeluaran rata-rata adalah $\mathrm{Rp}$ 15.000.000 - 17.000.000 perbulan. Pengeluaran terbesar $40 \%$ biaya makan, $40 \%$ biaya pendidikan (buku, transpor), 20\% pengelolaan (honor pengasuh, listrik, dan lainnya). Sehingga biaya pengembangan panti dan anak asuh sangat kecil bahkan tidak mencukupi.

Untuk itu, perlu direncanakan dan dikembangkannya usaha yang terarah dan berkesinambungan agar lembaga dapat memiliki dana yang cukup untuk pengembangan baik fisik dan non fisik, sehingga anak asuh dapat termaksimalkan proses pembinaanya. Budidaya ikan dan tanaman dalam ember (BUDIKDAMBER) yang dikembangkan oleh Julinursandi, Tenaga Pengajar di Politeknik Negeri Lampung, yaitu suatu teknik budidaya ikan dan sayuran yang menggunakan media ember (atau sejenisnya) untuk dijadikan lahan subtitusi kolam dan tanah pertanian untuk memelihara ikan dan menanam sayur. Budidaya ini cocok untuk dikembangkan dilahan sempit, landai, dan jauh dari sumber air (Nursandi, 2015). Budidaya ini diajukan untuk diterapkan di Panti Asuhan BM 2 dengan tujuan:

(1) Pemberian keterampilan perkebunan dan perikanan kepada anak asuh dan pengelola Panti Asuhan,

(2) Penyediaan secara mandiri kebutuhan pokok sayuran seperti kangkung, cabai, dan tomat, dan

(3) Penyediaan secara mandiri kebutuhan pokok protein seperti ikan lele. 
Sistem budidaya ikan dan tanaman yang menjadi satu dalam ember ini disebut juga akuaponik (Febri et al., 2019). Budidaya ini telah banyak diterapkan antara lain di daerah Aceh Tamiang (Febri et al., 2019), Tasikmalaya (Nasrudin et al., 2021), Jambi (Irfayanti \& Ningsih, 2020), dan Brebes (Syaifariz et al., 2020).

Panti asuhan BM 2 berdiri di lahan yang landai, beberapa bagian bergelombang, dan jauh dari pusat air membuat budidaya ini cocok untuk diterapkan ditempat itu. Lebih lanjut, dengan pelatihan dan pengawasan yang tepat, hasil budidaya dapat dikembangkan agar bernilai ekonomis dengan cara menjualnya ke penduduk sekitar. Sehingga, selain dapat menghemat biaya pengeluaran dapat juga menjadi salah satu sumber pendapatan (Sugiharti et al., 2020). Selain itu, manajemen pengelolaan juga sangat diperlukan agar Panti asuhan dapat berfungsi secara maksimal dalam melakukan pembinaan sehingga anak asuh tidak bergantung kepada orang lain dan menjadi masyarakat yang mandiri tanpa membebani masyarakat sekitar dan mampu merencanakan masa depan dengan baik (Mulyono and Yuliasari, 2015). Lebih lanjut panti asuhan dapat menjadi sentra pendidikan bagi masyarakat yang berada disekitarnya baik untuk pendidikan agama maupun ekonomi.

Program pengabdian ini direncanakan dilaksanakan selama periode tiga tahun Oktober 2019Desember 2022 yang dimulai dengan pembangunan budidaya dan diseminasi komersialisasi pada tahun pertama, pengembangan budidaya dan tahap diseminasi komersialisasi di tahun kedua, dan diakhiri dengan perbaikan model komersialisasi.

\section{METODE PELAKSANAAN}

Metode yang digunakan dalam pelaksanaan Program Pemberdayaan Ekonomi Mandiri Melalui Budidaya Perikanan dan Perkebunan dalam Ember (BUDIKDAMBER) adalah pelatihan dan pendampingan. Berikut kegiatan yang telah, sedang dan akan dilaksanakan:
1) Rencana kegiatan:

a. Pembangunan Budikdamber

a) Pembelian alat dan bahan

b) Pelatihan budikdamber

c) Instalasi

d) Uji coba

e) Implementasi

f) Perawatan

b. Peningkatan keterampilan, perikanan dan perkebunan, keuangan, dan pemasaran melalui pelatihan.

c. Pemberdayaan ekonomi melalui komersialisasi hasil perikanan dan perkebunan.

d. Evaluasi hasil pemberdayaan.

2) Waktu dan Tempat Pelaksanaan Kegiatan

Sesuai dengan surat tugas yang diterbitkan oleh Panti Asuhan Budi Mulya 2 nomor: 018/ PABM2/2019, kegiatan pengabdian kepada masyarakat ini akan dilaksanakan selama 3 tahun terhitung mulai 10 Oktober 2019 sampai dengan 31 Desember 2022 bertempat di Panti Asuhan Budi Mulya 2, Kemiling, Bandar Lampung. Jadwal kegiatan program pemberdayaan untuk tahun pertama dapat dilihat pada tabel 1 .

3) Peserta

Kegiatan program yang telah dilaksanakan diikuti oleh 12 anak asuh, pengurus dan pengasuh panti sebagai peserta pelatihan. Instruktur pelatihan terdiri dari empat orang dosen dari Institut Informatika dan Bisnis Darmajaya, tiga orang dosen dari Politeknik Negeri Lampung dan juga melibatkan empat orang mahasiswa dari IIB Darmajaya yang membantu dosen serta mendampingi peserta. Detail diperlihatkan pada tabel 2.

4) Pendanaan

Pendanaan kegiatan program pemberdayaan ekonomi mandiri melalui budidaya perikanan dan perkebunan dalam ember bersumber dari Badan Wakaf Indonesia (BWI) Provinsi Lampung sebanyak 90\% dan Panti Asuhan Budi Mulya II sebesar 10\% dari total modal. Modal yang berasal dari BWI merupakan pinjaman yang akan dikembalikan dalam kurun waktu tiga tahun cicilan.

Tabel 1. Jadwal Kegiatan Program Budikdamber Tahun 1

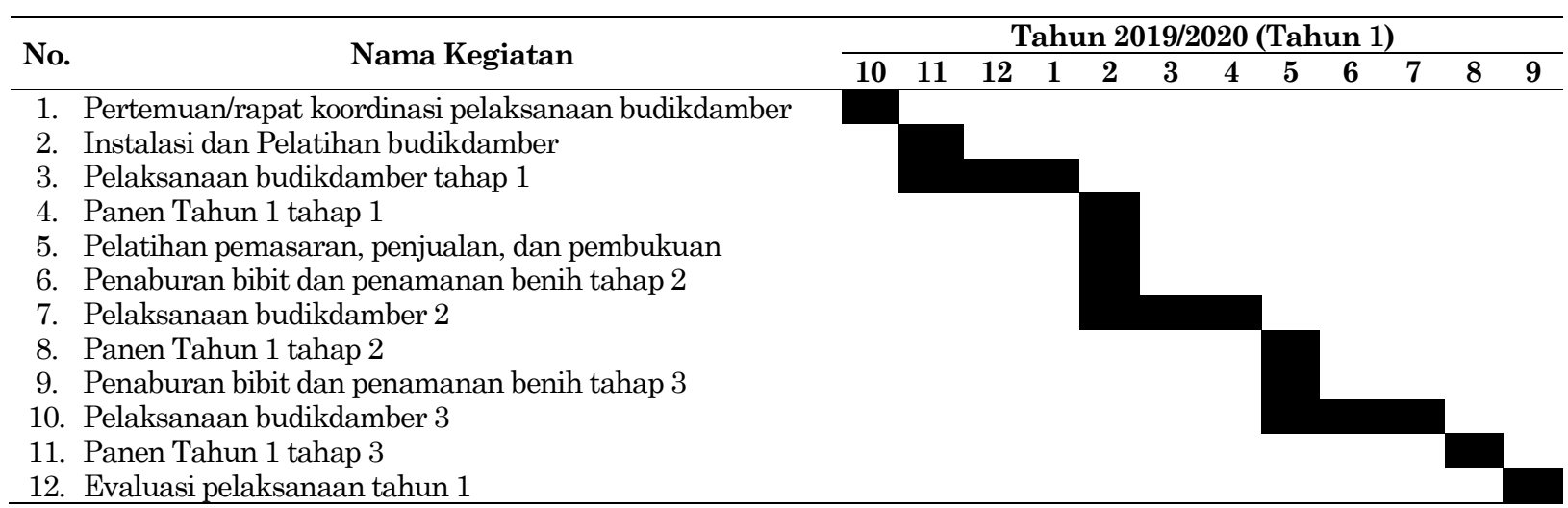


Tabel 2. Dosen dan Mahasiswa Peserta Program

\begin{tabular}{lll}
\hline No. Nama & Tugas & Asal Institusi \\
\hline 1. Rahmalia Syahputri & Koordinator program pemberdayaan ekonomi & IIB Darmajaya \\
2. Nurfiana & Pengawas dan Penjamin Mutu Pemberdayaan & IIB Darmajaya \\
3. Jaka Darmawan & Keuangan & IIB Darmajaya \\
4. Ari Widiantoko & Instalasi dan Perawatan & IIB Darmajaya \\
5. Juli Nursandi & Penanggung Jawab Teknik Budikdamber & Politeknik Negeri Lampung \\
6. Nur Indriyanti, & Teknik Budikdamber & Politeknik Negeri Lampung \\
7. Ana Khuswatun Mukharomah & Teknisi Budidaya Ikan & Politeknik Negeri Lampung \\
8. Arif Sofiyan & Membantu pelaksanaan program & Mahasiswa Fakultas Ilmu \\
9. Iqazduk Himam & & Komputer IIB Darmajaya \\
& Membantu pelaksanaan program & Mahasiswa Fakultas Ilmu \\
10. Adimas Aglasia & & Komputer IIB Darmajaya \\
& Membantu pelaksanaan program & Mahasiswa Fakultas Ilmu \\
11. Dicky Dwi Yudha & & Komputer IIB Darmajaya \\
12. Ahmad Suwardi & Membantu pelaksanaan program & Mahasiswa Fakultas Ekonomi \\
13. Berkat Fa'atulo Halawa & & Bisnis IIB Darmajaya \\
& Membantu pelaksanaan program & Mahasiswa Fakultas Ilmu \\
\hline
\end{tabular}

Tabel 3. Kegiatan Program PkM yang Sudah Dilaksanakan Periode Oktober 2019-September 2020

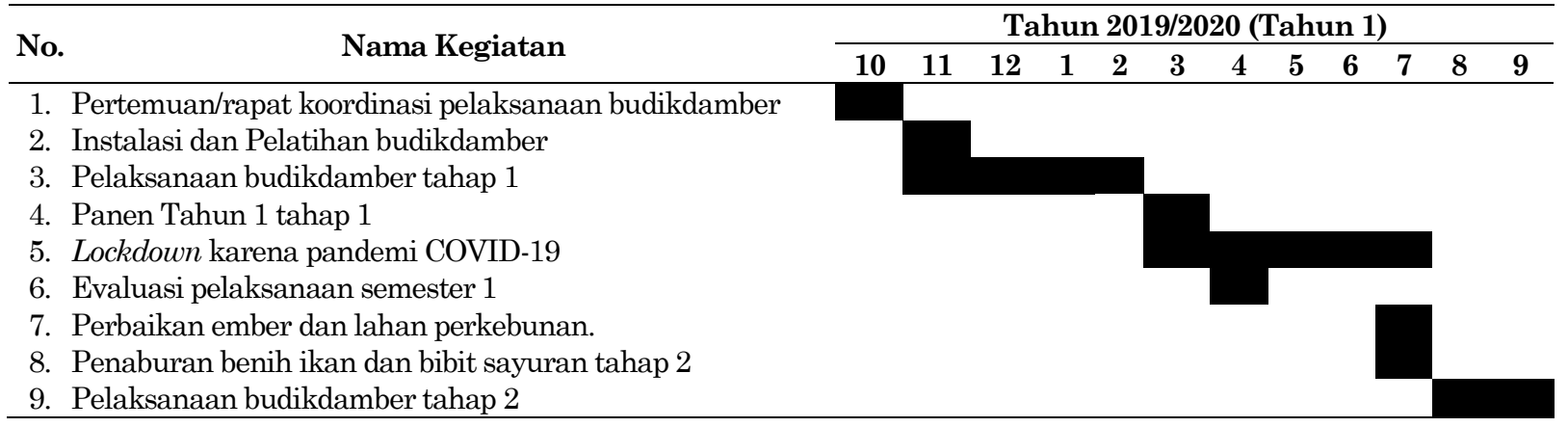

\section{HASIL DAN PEMBAHASAN}

Ringkasan kegiatan yang telah dilaksanakan pada tahun pertama dapat dilihat pada tabel 3 . Program dimulai dengan penandatangan nota kesepahaman antara Kepala Panti Asuhan dengan Ketua BWI Provinsi Lampung pada Oktober 2019. Setelah itu, dilaksanakan pertemuan dengan Pengurus panti dan anak asuh untuk memaparkan tujuan dan manfaat program ini. Budidaya ikan yang dikembangkan adalah 300 benih lele yang, sedangkan sayuran yang di tanam adalah kangkung air, kangkung akar, cabai merah, dan tomat. Detail kegiatan dipaparkan sebagai berikut:

\section{Persiapan Pelatihan dan Instalasi}

Tahap persiapan pelatihan dan instalasi dilakukan untuk mempersiapkan alat dan bahan apa saja yang dibutuhkan untuk membangun BUDIKDAMBER. Pada tahap awal dibutuhkan enam ember sebagai media penampungan dan benih ikan sebanyak 300 ekor. Cup bekas minuman sebanyak 60 buah disiapkan sebagai tempat menanam kangkung yang dibeli 5 kg, arang sebagai pengganti tanah dan kawat digunakan untuk mengaitkan cup ke pinggiran ember. Benih rampai dan cabai disiapkan sebanyak satu bungkus untuk disemai menggunakan enam pot bunga diatas media tanah. Peralatan lain seperti tang, solder, irik, dan selang juga disiapkan untuk pelatihan dan instalasi.

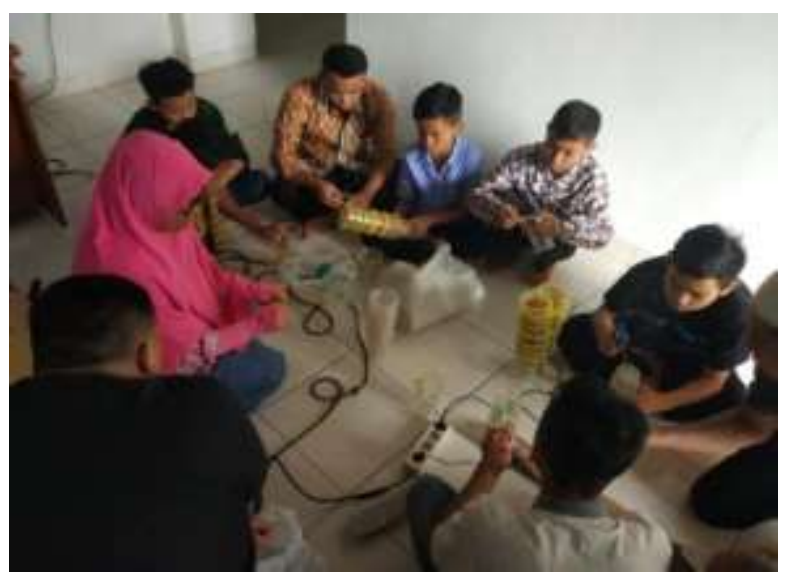

Gambar 1. Persiapan Pelatihan dan Instalasi 


\section{Pelatihan dan Instalasi}

Pelatihan dan instalasi dilakukan untuk memberikan keterampilan bagaimana merakit alat dan media yang diperlukan untuk menjalankan budidaya ini. Pelatihan yang dilakukan adalah membuat alat dan media budidaya, menanam benih, memberi pakan, dan menguras. Instalasi yang dilakukan adalah media tanam kangkung, tomat, dan cabai dan ember untuk ikan lele.

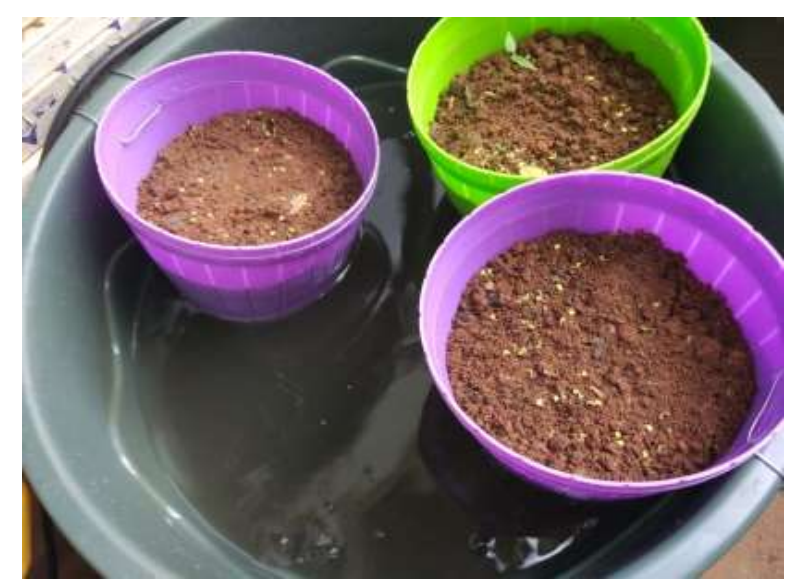

Gambar 2a. Instalasi Media Tanam Cabai dan Tomat

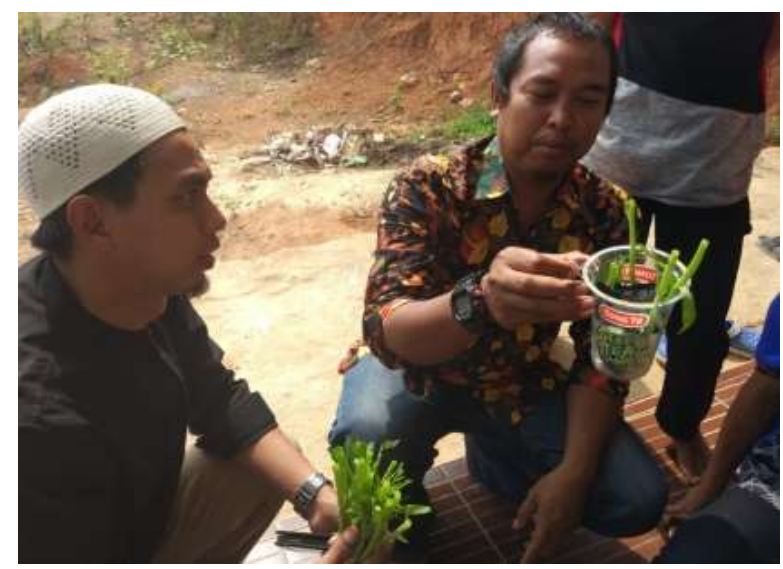

Gambar 2b. Instalasi Media Tanam Kangkung

\section{Perawatan}

Perawatan dilakukan dengan cara pemberian pakan ikan setiap hari sesuai jadwal pemberian makan. Pengurasan air yang warnanya sudah mulai pekat untuk diganti dengan air yang baru dilakukan minimal seminggu sekali. Memastikan tinggi air harus merendam cup tanaman sebatas arang agar kangkung tidak layu dan mati. Pemindahan lokasi BUDIKDAMBER dari area yang kurang terkena cahaya ke area yang mendapat cahaya matahari langsung agar tanaman tumbuh lebih baik dan air dalam ember tidak cepat berbau. Setiap tiga hingga empat pekan sekali sekali dilakukan sorting ukuran ikan agar ikan berada dalam satu ember yang sama ukurannya. Selain itu, dibuat dan dipasang pagar pengaman karena lokasi panti yang di kaki bukit dan belum banyak penduduk yang bermukim disana.

Melalui kegiatan ini anak asuh dilatih untuk disiplin terhadap jadwal, bertanggung jawab terhadap tugasnya masing-masing, dan peka terhadap kondisi budidaya. Sedangkan pengasuh anak (pengurus yang bermukim di panti untuk mengawasi dan mendapingi anak asuh setiap harinya) dilatih untuk membuat jadwal perawatan budidaya dan pengawasan dan kontrol kegiatan anak.

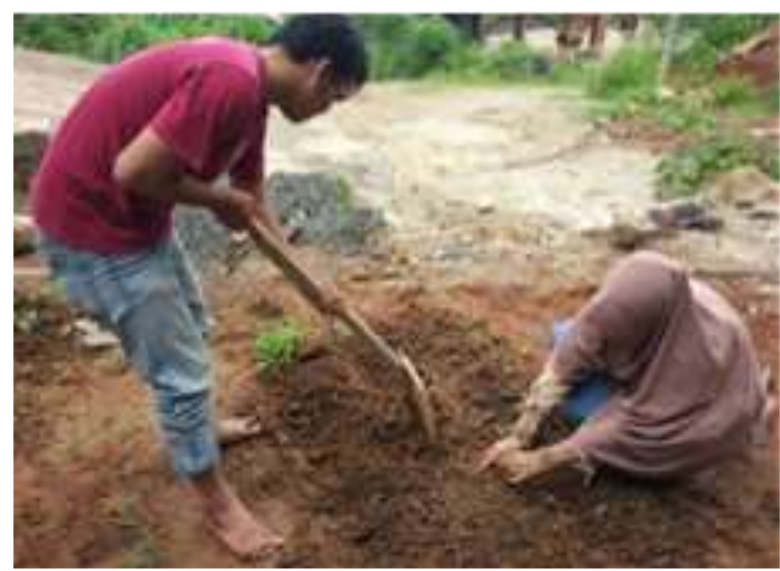

Gambar 3a. Pemindahan Tomat dan Cabai ke Bidang Tanah Luas

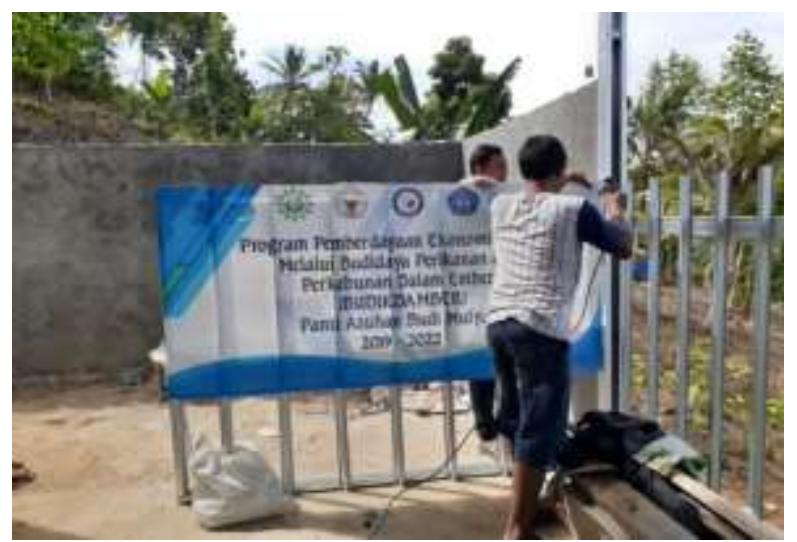

Gambar 3b. Pembuatan dan Pemasangan Pagar Pengama

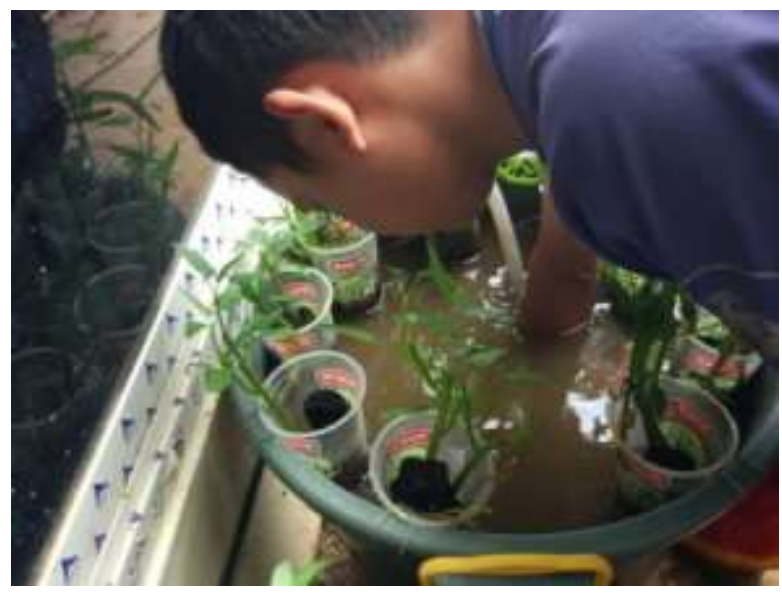

Gambar 4a. Pengurasan Ember 


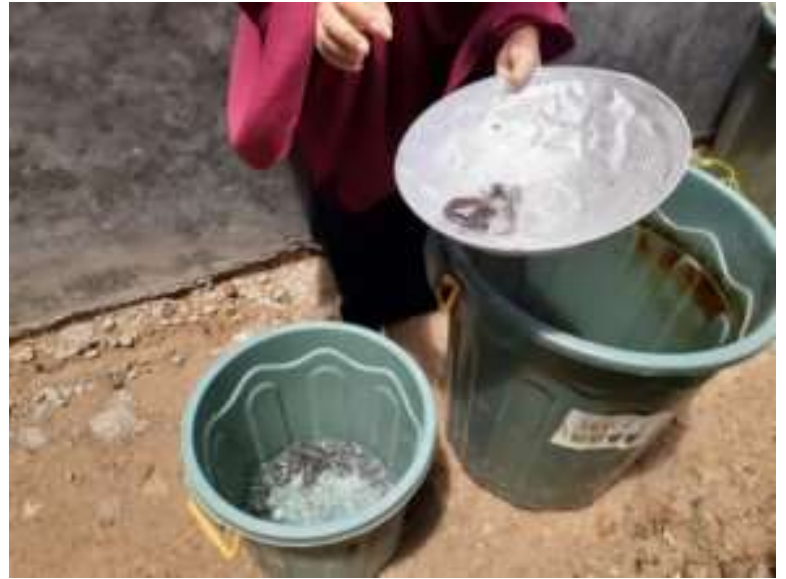

Gambar 4b. Pemisahan Ikan Berdasarkan Ukuran (Sortir)

\section{Panen}

Setelah ikan dan sayuran siap untuk di panen dan untuk mengenalkan program ini ke masyarakat luas, dilakukan panen raya dan lelang. Kegiatan ini mengundang berbagai elemen masyarakat antara lain Ketua dan Pengurus BWI Provinsi Lampung, Ketua dan Pengurus panti asuhan BM2, Mualaf Center Provinsi Lampung, LP4M IIB Darmajaya, Peneliti Politeknik Negeri Lampung, dan Donatur tetap Panti (Paparan Lampung, 2021). Khusus untuk tanaman kangkung air dan akar, telah dilaksanakan panen berulang sebanyak lima kali dalam kurun waktu 3,5 bulan. Sedangkan tanaman cabai belum siap panen karena masih hijau yang kemungkinan baru bisa dipanen 1 bulan kedepan (Priyono, 2017).

Panen menghasilkan $10 \mathrm{~kg}$ ikan, tiga kg kangkung, dan tiga kg tomat. Pada putaran pertama ini fokus bukan pada komersialisasi, melaikan pembangunan budidaya dan melatih pengasuh dan anak asuh untuk melaksanakan budidaya tersebut. Dilakukan pelelangan terhadap $5 \mathrm{~kg}$ ikan lele, $1 \mathrm{~kg}$ kangkung, dan $1 \mathrm{~kg}$ tomat. Hasil lelang sebanyak Rp. 500.000 yang disimpan untuk menambah dana pengembangan budidaya. Sedangkan ikan dan sayuran yang dilelang, oleh pembeli, dikembalikan ke pengasuh panti untuk dimasak dan dikonsumsi bersama.

Secara mendadak, pada pekan ke tiga ada pengumuman pemerintah bahwa diberlakukan isolasi dan pembatasan mobilitas karena pandemic COVID-19. Hal ini mengakibatkan diberhentikannya sementar program pemberdayaan dan anak asuh dikembalikan ke keluarganya karena panti dikosongkan.

Selama lockdown, dilakukan pertemuan daring untuk menindaklanjuti hasil evaluasi dan penyelenggaraan kembali BUDIKDAMBER. Setelah mendapatkan informasi bahwa telah diijinkan ber- aktifitas terbatas di luar rumah dengan penerapan protokol kesehatan yang ketat, maka kegiatan budidaya ini dilanjutkan kembali pada pertengahan Juli 2020. Program BUDIDAMBER tahap dua dimulai dengan perbaikan beberapa alat yang telah rusak dan pembelian alat yang tidak bisa diperbaiki. Kemudian dilanjutkan dengan pembukaan lahan untuk menamanan benih sayuran selada, pakcoy, tomat, dan cabai. Penaburan benih ikan dilakukan pada 28 Juli 2020.

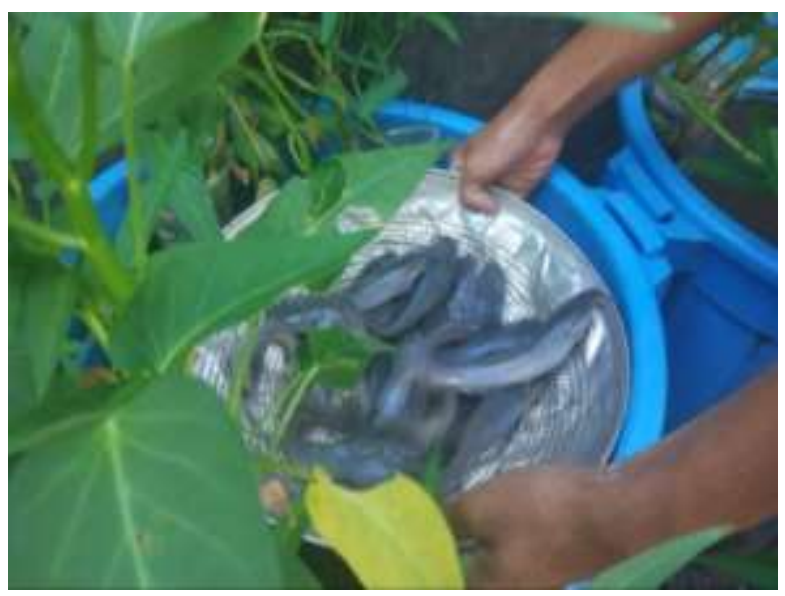

Gambar 5a. Panen Ikan

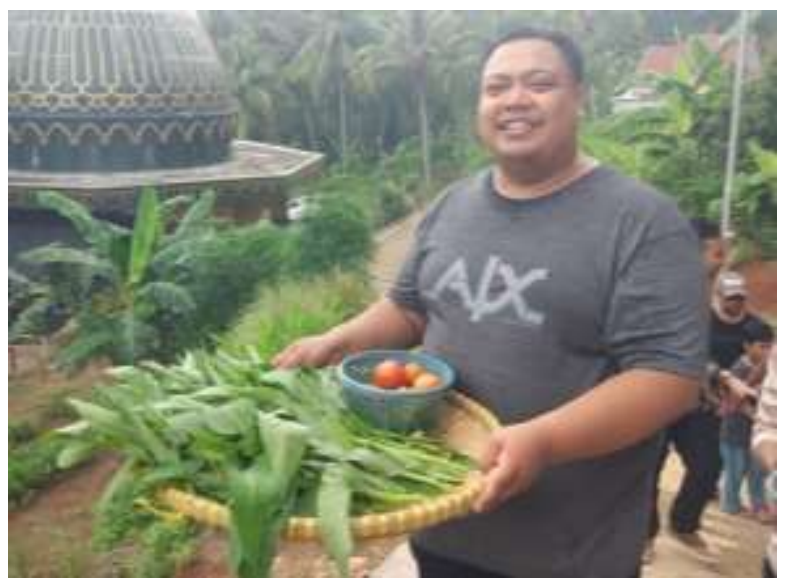

Gambar 5b. Hasil Panen Kangkung dan Tomat

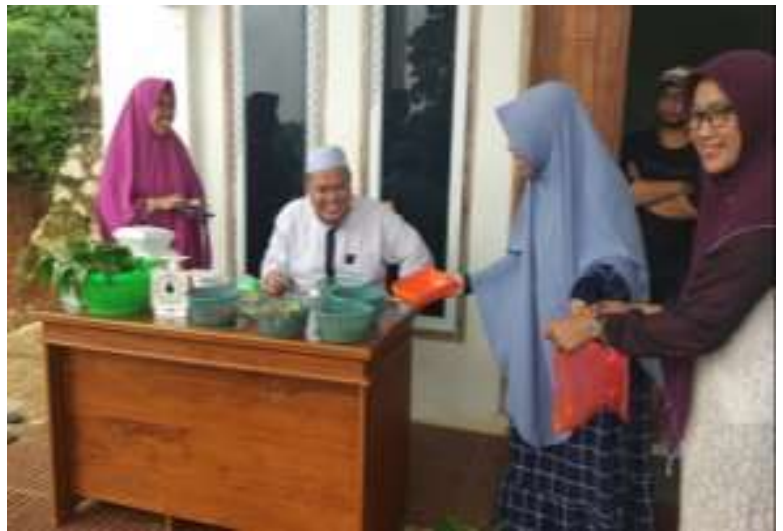

Gambar 6. Lelang Hasil Panen 
Perawatan dilakukan dengan melibatkan hanya dua anak asuh, mahasiswa, dan dosen karena sebagian besar dari anak masih melaksanakan isolasi mandiri di daerah masing-masing. Pada September 2020, telah dilakukan dua kali sorting dan tingkat kematian masih tinggi sebesar 33,33\% di minggu pertama.

\section{Evaluasi}

Evaluasi program dilakukan pada Maret dan Juli 2020, dengan hasil:

a. Tingkat kematian ikan pada tahap satu dan dua cukup tinggi namun masih dalam cakupan perkiraan yaitu $30-50 \%$.

b. Pelatihan keuangan dan pemasaran digital belum berhasil dilaksanakan karena pandemi.

c. Sinergi monitoring antara dosen pengabdi dan Pengasuh panti yang masih kurang.

d. Tanggung jawab anak asuh dalam merawat budidaya yang masih kurang.

\section{SIMPULAN DAN REKOMENDASI}

Berdasarkan hasil pelaksanaan kegiatan pengabdian kepada masyarakat yang telah dilakukan di Panti Asuhan Budi Mulya 2, dapat ditarik beberapa simpulan sebagai berikut:

1) Pengasuh dan Anak asuh telah mendapatkan keterampilan dasar dalam budidaya ikan dan tanaman di dalam ember.

2) Sebagian fungsi lahan kosong pada panti telah dimanfaatkan menjadi lahan tanaman yang menghasilkan dan dapat dikonsumsi untuk memenuhi kebutuhan panti.

Adapun rekomendasi yang dapat diberikan berdasarkan pelaksanaan dan hasil evaluasi adalah:

1) Peningkatan keterampilan pengurus dan anak asuh dalam BUDIKDAMBER.

2) Perlunya pendampingan berkala dan berkesinambungan.

3) Sinergitas pelaksanaan monitoring program perlu ditingkatkan.

4) Peningkatan fungsi lahan kosong yang dikembangkan menjadi lahan tanaman dan perikanan yang menghasilkan dan memenuhi kebutuhan panti.

5) Pengembangan program budidaya.

6) Penambahan sumber pendanaan program.

\section{UCAPAN TERIMA KASIH}

Kami mengucapkan terimakasih kepada Pengurus, Pengasuh, dan Anak asuh panti asuhan Budi Mulya 2 yang telah memberikan kami kesempatan untuk melakukan kegiatan pengabdian masyarakat dan membantu pelaksanaan program Badan Wakaf Indonesia Provinsi lampung atas bantuan modal yang diberikan, Tim Pengabdian, Masyarakat sekitar, dan Mahasiswa IIB Darmajaya Fakultas Ilmu Komputer dan Ekonomi Bisnis.

\section{DAFTAR PUSTAKA}

Departemen Sosial. 2018. Artikel Lembaga Kesejahteraan Sosial Anak (LKSA). (n.d.). https://dinsos.bulelengkab.go.id/informasi/detail/artikel/ lembaga-kesejahteraan-sosial-anak-lksa-93. [Diakses 21 Juli 2021].

Febri, S. P., Alham, F., \& Afriani, A. 2019. Pelatihan BUDIKDAMBER (Budidaya Ikan Dalam Ember) di Desa Tanah Terban Kecamatan Karang Baru Kabupaten Aceh Tamiang. Prosiding Seminar Nasional Politeknik Negeri Lhokseumawe, 3(1), C112-C117.

Irfayanti, D., \& Ningsih, P. 2020. Kemandirian pangan dengan pembuatan budikdamber (budidaya ikan dalam ember) di kecamatan Telanaipura kota Jambi. Jurnal Pembelajaran Pemberdayaan Masyarakat, 1(4), 350-355.

Mulyono, E. S., \& Yuliasari, N. R. 2015. Peran Pengelola Panti Asuhan dalam Upaya Meningkatkan Kedisiplinan Anak Asuh. Jurnal Pendidikan Nonformal, 4(2).

Nasrudin dan Nurhidayah, S. 2021. Budikdamber Guna Menjamin Ketersediaan Pangan Saat Pandemi Covid-19 di KWT Mawar Bodas Kota Tasikmalaya. Jurnal Pengabdian Masyarakat, $4(1), 33-37$.

Nurfiana, N. 2020. Pemanfaatan Teknologi Location Based Service untuk Pencarian Lokasi Panti Asuhan Berbasis Android. Jurnal Ilmiah Teknologi Informasi Dan Robotika, 2, 24-29.

Nursandi, J. 2015. Budidaya Ikan Dalam Ember "Budikdamber" dengan Aquaponik di Lahan Sempit. Prosiding Seminar Nasional Pengembangan Teknologi Pertanian, VII(2013), 129136.

Paparan Lampung. 2021. Hibah PKM, Tiga Dosen IIB Darmajaya Lakukan Pendampingan SOP Blended Learning SMA IT Ar Raihan. (n.d.). https://paparanlampung.com/hibah-pkm-tigadosen-iib-darmajaya-lakukan-pendampingansop-blended-learning-sma-it-ar-raihan/. [Diakses 22 Juni 2021].

Peraturan Pemerintah. 1988. PP No. 2 Tahun 1988 tentang Usaha Kesejahteran Anak Bagi Anak Yang Mempunyai Masalah [JDIH BPK RI]. (n.d.). https://peraturan.bpk.go.id/Home/Details/ 63839/pp-no-2-tahun-1988. [Diakses 21 Juli 2021].

Priyono, W. 2017. Masa Panen Cabe Merah yang Baik dan Benar (Studi Kasus Di Lapangan)TipsPetani.(n.d.). https://tipspetani.com/masapanen-cabe-merah-yang-baik-dan-benar-studikasus-di-lapangan/. [Diakses 21 Juli 2021] 
Sugiharti, R., Viana, D. N., \& Khabibah, N. A. 2020. Budikdamber (Budidaya Tanaman Dan Ikan Dalam Ember) Untuk Mendukung Program Kampung Organik Di Kampung Dumpoh Kota Magelang. Jurnal Untidar, 4(1), 34-41.
Syaifariz, A., Nursidik, A. A., Khotimah, N. K., \& Khairun, M. T. 2020. Budikdamber Sebagai Stategi Penguatan Ketahanan Pangan dan Perekonomian Masyarakat Kabupaten Brebes di Tengah Pandemi. Jurnal Abdidas, 2, 41-47. 